INTERnational JOURNAL OF MULtidisciplinaRy Research AND ANALysis

ISSN(print): 2643-9840, ISSN(online): 2643-9875

Volume 05 Issue 02 February 2022

DOI: 10.47191/ijmra/v5-i2-17, Impact Factor: 6.072

Page No. $355-358$

\title{
Outstanding Manuscripts of The "Bukhara Collection" of The Institute of Oriental Manuscripts of The Russian Academy of Sciences (St. Petersburg)
}

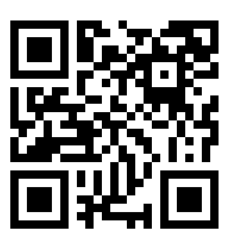

\section{Shakhnoza Ganiyeva (Amirova)}

Senior Lecturer Academy of Arts of Uzbekistan National Institute of Arts and Design named after Kamoliddin Behzod Tashkent, Uzbekistan

ABSTRACT: Outstanding manuscripts created on the territory of Uzbekistan in ancient, powerful states - in Khorasan and Maverannakhr, represent a fund of priceless manuscripts and folios in the Institute of Foreign Affairs of the Russian Academy of Sciences, among which there are genuine unique ones. They were acquired by the institute and thanks to scientific missions of the institute's employees, starting from the end of the 19th century. One of the most valuable collections is the Bukhara Collection by Vladimir Ivanov. About some unique folios acquired by the St. Petersburg scholar in Bukhara, and will be discussed in this story.

KEY WORDS: Bukhara, collection, manuscripts, scientific works, works of art, Sufism, archaeography.

\section{INTRODUCTION}

The emergence of the first Central Asian collections in Russia is closely connected with the history of Oriental studies. Oriental studies, as a science, was necessary, first of all, for the development of Russian statehood, constant interaction with the peoples that were part of the Russian Empire, had their own culture and professed different religions. After all, most of the territory of this power is in Asia. In addition, infinitely long lines of borders with the countries of the East, trade and diplomatic relations required people who knew the East.

\section{THE MAIN RESULTS AND FINDINGS}

Since the end of the 17th century in Russia, they began to purposefully collect manuscripts in Eastern languages, as well as household items and cult of the countries of the East.

The first manuscripts in Arabic script came to Russia from trips to Muslim regions. Oriental books were also acquired by private collectors in Europe.

However, from the time of the creation of the first oriental collections to the creation of a truly scientific, in fact, Russian oriental studies, almost a whole century will pass. In this regard, it is difficult to overestimate the importance of the Asian Museum, which has become a kind of bridge between East and West. At the origins of the creation of the Asian Museum were not only scientists, but also statesmen, for whom it was important that the collections, as well as sources in the languages of the East, be stored in St. Petersburg, studied and published.

The creation of the Asian Museum marked the beginning of a new period - academic oriental studies in Russia. The Asian Museum gradually became one of the world's largest collections of Oriental folios and manuscripts and the main, the earliest in Russia, institution for the fundamental scientific study of the East.

In this study, special attention is paid to the collections of manuscripts that were created in the ancient cities of Uzbekistan, but by the will of fate ended up in St. Petersburg in the Asian Museum, the successor of which was the Institute of Oriental Manuscripts of the Russian Academy of Sciences, where the manuscript masterpieces of the Muslim collection are currently stored.

In 1912, the Muslim fund of the Asian Museum received a unique list of the famous work of the great oriental scholarencyclopedist Abu Rayhan Biruni (Abu Rayhan Muhammad ibn Ahmed al-Biruni, 973-1048) - the manuscript "Kitab Al-osor al- 


\section{Outstanding Manuscripts of The "Bukhara Collection" of The Institute of Oriental Manuscripts of The Russian Academy of Sciences (St. Petersburg)}

bokiya an al-kurun al -cholia" ("Monuments of past generations"). The list, which entered the Asiatic Museum, was rewritten almost 200 years after the scientist's death in 1220-1221. Science does not know the source of the manuscript in the Asian Museum. In Europe, this work of Biruni is known under the name "Chronology", and in the East - "Osor al-boqia". The historical work, in the center of which is the genealogy and chronology of the largest dynasties of the Near and Middle East, was created by the scientist in 1000, when he was 27 years old. The manuscript includes the calendar systems of many peoples and chronological tables of historical events. In addition, this fundamental work is devoted to the history and culture of Khorezm and neighboring states of the East.

The Muslim fund of the Institute of Oriental Manuscripts of the Russian Academy of Sciences was replenished thanks to the expeditions of the Institute to Central Asia. The first of them took place at the suggestion of Vasily Bartold (1869-1930) in 1914 in the Turkestan region "to search for and acquire Muslim manuscripts". And already in the next year, in 1915, an individual archaeographic expedition was undertaken to Bukhara by an orientalist linguist, poet and translator, Vladimir Ivanov (1886-1970). Since 1915, the scientist worked as a junior curator of the Asiatic Museum. More than one thousand, or rather 1057 manuscripts were bought by him in Bukhara and delivered to the Asian Museum. This is the so-called Bukhara collection. It is a collection of priceless Muslim manuscripts reflecting the intellectual life of not only Bukhara, but the entire Maverannahr for several centuries. These are works on theology, history, geography and outstanding works of fiction and poetry of the East. The manuscripts were rewritten several times. For example, in the Emirate of Bukhara, permission to make copies of the manuscript and its authenticity was confirmed by the imam of Bukhara. After a complete comparison of the manuscript with the existing original, the imam, in the presence of witnesses, issued a document confirming the correctness of the copy, and sealed it with his signature and seal. Manuscripts copied without permission were considered worthless. These facts testify to how much the manuscripts were valued and played a huge role in the cultural life of the enlightened electorate of Bukhara.

The results of the 1915 expedition were called "brilliant" in the Asian Museum. In the report of the museum for this year, the activities of Vladimir Ivanov were especially noted: "such brilliant results of the collective activity of Mr. Ivanov are due to his tireless zeal and experience in relations with Eastern booksellers, acquired during his travels ...". Along with the replenishment of the manuscript collection, the process of its cataloging and the study of individual literary monuments was going on almost simultaneously in the Museum. The handwritten book becomes the source of the most important base for any research. The composition of the manuscripts of the Bukhara collection is diverse both in the time of their census and in the place of their origin. The earliest examples date back to the 11th century. These are comments on the Qur'an "at-Taysir fi tafsir an-Nasafi" by Najmuddin Abu Hafs Umar ibn Muhammad ibn Ahmad an-Nasafi al-Hanafi as-Samarkandi (1067-1142), a famous Islamic theologian, interpreter of the Koran, author of more than a hundred works of religious content and philosophical treatises. Ivanov's Bukhara collection contains several lists of interpretations of the Koran, among them "al-Kashshaf an haqaik at-tanzil" by the famous Khorezmian az-Zamakhshari (Abu-I-Kasim Mahmud ibn Umar al-Zamakhshari, 1074 - 1143). In addition to Koranic texts and religious works, Ivanov's collection included scientific and philosophical treatises, works of oriental poetry and artistic prose. The pearl of the collection is another work by Zamakhshari "Tahafut al-falsif" - "The overthrow of the philosophers". Among the manuscripts of the Ivanov collection was a rare copy of the dictionary of Ismail ibn Hammad al-Jawhari (940-1003) "As-Sikhah fi al-lugat" ("The crown of speech and the correct words of the Arabic language"), rewritten in the 13th century, which is one of the main Arabic medieval dictionaries. The dictionary provides absolutely reliable information on the pronunciation and grammar of more than 40,000 Arabic words and expressions. In addition, the author described in detail the origin and meaning (isox) of each word included in his work. The dictionary, created by the author between the second half of the 10th century and the beginning of the 11th century, was rewritten in 1253 . The list, which V. Ivanov brought to St. Petersburg, was personally sealed with the seal of the Bukhara ruler Subkhankuli Muhammad Khan (1625-1702). It can be assumed that the manuscript, copied in the middle of the 13th century, was kept in the kitabkhana of the Bukhara emirs already in the 17th century.

Of particular value to the collection are handwritten books from the library of the sheikh of the Naqshbandi Sufi brotherhood - Muhammad Pars, whose year of birth varies from 1345 to 1355 (d. 1420). "In the Bukhara collection, the main thing, if not in quantity, then in quality, the place belongs to the remains of the library of the Central Asian figure, the head of the Sufi Nakshbendi order, the second successor of Bukhaaddin an-Naqshbend - Muhammad Pars. Most of the best and most valuable manuscripts of the collection belong to this library", we read in the study "Arabic Manuscripts" by Viktor Belyaev. In this collection, the manuscript with the work of Muhammad Pars "The Circumstances of High Mecca" was created in 1576.

Ivanov's collection also included the manuscript "Nafakat al-uns min qadarat kuts" - "Blows of friendship from the cloisters of holiness" by Abdurakhman Jami (Nuriddin Abdurrahman ibn Ahmad Jami, 1414-1492). This work includes a chronicle 


\section{Outstanding Manuscripts of The "Bukhara Collection" of The Institute of Oriental Manuscripts of The Russian Academy of Sciences (St. Petersburg)}

of the life of 616 sheikhs, saints and scholars who lived in the XIII-XIV centuries. In the description of the catalog of the Muslim Foundation, it is written that there are more than thirty women among them. This work was created by Jami in 1475-1477 under the influence of the works of Abdullah Ansari (1006-1088) "Tabaqat as-Sufi" and Fariddin Attara (1156-1220) "Tazkirat al-avliya", which are stored in the Muslim fund of the Institute (D330). Some sources contain information that Abdurakhman Jami created this treatise at the request of Alisher Navoi, who, in response to Jami's "Nafakat al-uns", created an anthology in the Uzbek language "Nasaim al-muhabbat", which includes stories about the life of 770 poets and saints. Jami's list from Ivanov's collection was copied in Bukhara. However, there is no exact date for the census of the manuscript. The catalog indicates a possible date starting from 1829.

The Institute of Oriental Manuscripts of the Russian Academy of Sciences has a manuscript with one of the most famous works of Abdurakhman Jami - "Yusuf and Zuleikha", which is one of the seven poems included in "Haft Avrang" - "Seven Thrones". Jami created this poem in 1483, already being a well-known poet and Sufi in the East. During his lifetime, Jami enjoyed great respect. Scientists from all over Maverannahr, India, Iran, Asia Minor and Arabia corresponded with him, and some of them came to Herat to meet him personally. His 337 autographs have been preserved in various manuscript collections of the world. Jami's list "Yusuf and Zuleikha" was rewritten in 1823. It is a unique piece of manuscript art, since from the cover to the final colophon, it is decorated with colorful miniatures corresponding to each fragment of the content. 83 years after its creation, this folio ends up in Ivanov's collection.

The pinnacle of literary creativity of Abdurakhman Jami is considered "Bakharistan" - "Spring Garden". This work in rhymed prose was created by the poet in 1482. The list from Ivanov's collection was copied in Kokand in the first half of the 19th century (1835-1836). Researchers compare Jami's "Spring Garden" with the famous work of his brilliant predecessor Saadi (Muslihiddin Abu Muhammad Abdallah ibn Mushrifaddin Shirozi, 1210-1292) - "Gulistan". Both poems have an introduction and eight chapters - "gardens" and are practically presented in a single manner. Jami's Baharistan has been translated into Latin and many European languages.

Ivanov's collection included several "Divans" (collections of poems), the greatest lyric poet of the East, Hafiz Shirazi (Shamsiddin Muhammad Hafiz Shirazi, 1326 - 1389), rewritten at different times in Bukhara. One of them, which is rightfully considered the most valuable example of the art of the Maverannakhr manuscript, was created in Bukhara in the 19th century (the exact date of the census is not available). The manuscript is richly decorated with miniatures dominating several pages and ornamented with floral designs. Despite the fact that the poet wrote only in Farsi, his works were copied throughout the East, including in the states on the territory of present-day Uzbekistan. This collection has a preface, compiled after the death of the poet, according to scientists from the Institute of Contemporary Art of the Russian Academy of Sciences (A. Khismatulin).

Each of the masterpieces of book art has its own history and destiny. It is quite obvious that they were the result of the needs of high-ranking customers and were created by outstanding masters of manuscript art.

\section{CONCLUSION}

The states that once flourished on the territory of Uzbekistan were ruled by enlightened rulers who possessed priceless collections of manuscripts and folios. Timurid Herat, Bukhara, the capitals of the great Baburids in India - they were famous for their book treasures. The illustrated manuscripts of the "Bukhara Collection" are exquisite, filled with wisdom, philosophy, legends, and exceptional intelligence of poets and thinkers who left us unforgettable images of their heroes, who continue to live in priceless manuscripts created in the royal libraries by a galaxy of talented calligraphers, miniaturists and gilders.

\section{REFERENCES}

1) Biruni Abu Rayhan. Monuments of past generations. Volume. 1. -Tashkent. Fan. 1968, p. 41.

2) Asian Museum. -M. The science. // Main edition of Eastern literature. 1972. p. 28.

3) Belyaev V. Arabic Manuscripts. // Bukhara collection of the Asian Museum. -Leningrad. Academy of Sciences. 1959, p. 5

4) Collection of the Institute of Oriental Manuscripts of the Russian Academy of Sciences (St. Petersburg). Volume VII. Tashkent. Zamon Press Info. 2017. P. 298.

5) Doniyorov, A. K., \& Karimov, N. R. (2020). An incomparable book of a great scholar. Bulletin Social-Economic and Humanitarian Research, (6), 63-71.

6) Odilov, B. A., \& Karimov, N. R. (2020). Analysis of Targeted Research in 20-30 Years of the XX Century. PalArch's Journal of Archaeology of Egypt/Egyptology, 17(6), 8887-8893. 
Outstanding Manuscripts of The "Bukhara Collection" of The Institute of Oriental Manuscripts of The Russian Academy of Sciences (St. Petersburg)

7) Orifjonova, G. R. Q. (2019). Ethnographic collections of museums in Uzbekistan: samples of copper-embossing art. Muzeológia a kultúrne dedičstvo, 7(1), 235-240.

8) Orifjonova, G. R. (2018). ETHNOGRAPHIC COLLECTIONS OF THE STATE MUSEUM OF TEMURIDS'HISTORY: SAMPLES OF ART OF COPPER-EMBOSSING. ISJ Theoretical \& Applied Science, 4(60), 309-312.

There is an Open Access article, distributed under the term of the Creative Commons Attribution - Non Commercial 4.0 International (CC BY-NC 4.0)

(https://creativecommons.org/licenses/by-nc/4.0/), which permits remixing, adapting and building upon the work for non-commercial use, provided the original work is properly cited. 